\title{
Blood Feud and Its Impact on the Albanian Criminality
}

\author{
Vera Kopsaj \\ PhD Candidate, Department of Social and Economic Sciences, Sapienza University of Rome \\ vera.kopsaj@uniroma1.it
}

\section{Doi:10.5901/mjss.2016.v7n3s1p88}

\begin{abstract}
Blood feud in Albania still exists. It is spread throughout the country, but it is more alarming in northern Albania. The purpose of this study is to explore and describe the phenomenon in order to know its impact on the Albanian criminality. The literature review indicates that blood feud in Albania is adaptable to circumstances and it is associated with the weakness of the state. The analysis is based on combining data from different sources. The data show that during the years 1992-2012, the 7 Albanian districts out of 36 where blood feud is more present have a higher crime rate. The district of Shkodra, where Kanun has more influence, registers the highest crime rate. The results thus indicate that blood feud could be considered a significant criminogenic factor. Comparing to other countries taken into analysis Albania has, after Montenegro, the highest crime rate among Balkans. The data also show that blood feud does not have a great impact on a larger scale, since Albania ranks 14th out of 26 analysed countries for years 2006-2010.
\end{abstract}

Keywords: Blood feud, Kanun, institutional trust, crime.

\section{Introduction}

Violence is one of the most debated issues in the international forum. The presence of a multiplicity of moral codes all over the world makes violence a very sensitive issue. Its definition depends on actors and their purposes (Krug et al., 2002). The Albanian Kanun of Lek Dukagjini is one of these moral codes. It legitimates violence under particular conditions. A special section of Kanun pronounces that the blood never remains unavenged. It cannot be extinguished by a fine (II Kanun, art. 128, § 917). This moral obligation has a relevant effect on people engaged in blood feud, making them justify the committed homicides. If they kill for blood feud are considered heroes, not criminals. Although blood feud is a longstanding phenomenon, Albania still has to deal with it. Kanun belongs to the $15^{\text {th }}$ century, but still many people put it into practice. Indeed, there are thousands of people in Albania who struggle every day against blood feud. Moreover, there are hundreds of families locked in their houses turned into jails. The fear of being killed for blood feud force both adults and children, especially males, to stay hidden or to move stealthily. Children cannot attend school, they cannot play outside. They cannot live their childhood. They grow up in a context of hate, of violence, with the hope to become old enough to kill in turn. Blood feuds thus generate ignorance, hate and violence.

Nevertheless, the blood feud phenomenon is underestimated by the Albanian government. It considers it a local issue concentrated on a specific area, which has not got a significant impact on the whole society. The literature suggests the contrary. It shows that blood feud is present throughout the country. Furthermore, blood feud is strongly associated with the weakness of the state. The weakness of the state has pushed people to re-trust Kanun, the customary right, since it has precise rules concerning every aspect of life.

In this study we view the phenomenon from a sociological perspective. The statistical analysis shows that blood feud is a criminogenic factor: it significantly affects the Albanian crime rate.

\section{Purpose and Methodology}

The purpose of this study is to explore the uncontrollable nature of blood feud, in order to know the impact that it has on the Albanian criminality. Through the literature review we also seek to explore the roots of blood feud and its several aspects that has assumed during the years taken into analysis.

The limitation and the specific structure of the available data lead the analysis. That is, the fact that the available quantitative data focus on only 7 Albanian districts out of 36, reporting data only for the years 1992-2012, limits the freedom of choice of the methods to be used and consequently the analysis.

The descriptive analysis is based on the data drawn from the Albanian Committee of Nationwide Reconciliation, an 
Albanian NGO; the INSTAT database, the Albanian National Statistical Institute; and Worldbank. The Justice and Peace Commission of Albania and Caritas Albania (JPCA), also offered accurate data concerning the trust of people in the Albanian Justice Institutions and specific data for the district of Shkodra. The analysis focuses on 7 Albanian districts out of 36, the ones in which blood feud plays a more significant part. It covers 21 years, 1992 to 2012. Furthermore, the analysis is extended to a comparison on terms of intentional homicides between Albania and Europe and Central Asia. Such a comparison has been done in order to know the relevance of the phenomenon outside the Albanian frontiers. That is, the impact that the Albanian blood feud has on a larger scale.

\section{Literature Review}

There is a wide variety of literature about the Albanian blood feud and the Albanian customary right. Blood feud in Albania, especially in northern Albania, has attracted the attention of several English, German, American and Italian scholars.

'The XIX-th century was the starting point of the interest about the Albanian custom's right from foreign researchers.' (Bevapi, 2012: 117). During this time period blood feud was interpreted in comparison with other Balkan countries, focusing mainly on its historical and juridical aspects. At the beginning of the $20^{\text {th }}$ century several significant fieldworks helped to better comprehend the blood feud phenomenon, considering the fact that in that time Kanun was orally transmitted. The studies concerning blood feud in northern Albania are essentially coming from anthropology.

In this section we are going to consider that part of literature that enlightens the perspective of our analysis. That is, blood feud and the mythology; the organisation of the northern kinship and blood feud as a moral obligation; the mistrust of the Albanian Justice Institutions; the static and the dynamic aspects of blood feud. Such an excursus will help us to view the phenomenon over time, with its several aspects. It will also help to highlight the uncontrollable nature that blood feud has assumed during the years taken into analysis.

\subsection{Blood feud and mythology}

Blood feud is strongly connected with the mythology. The centuries-old oral transmission has covered Kanun with mythical charm, strengthening thus its legitimacy. On the one hand, a myth is important for a given community because it gives to it a shared past and a shared future, both essential for its existence. It helps the community to construct its own identity (Schöpflin, 2002). On the other hand, a myth can become such independent, with its own structure, that might be difficult to keep it politically under control. 'When myths become politically controlled there is little space for deviant thought.' (Schwandner-Sievers; Fischer, 2002: 20). In contrast, when myths are not politically controlled, authorities have little power on controlling deviant thoughts and actions. It seems that Albania presents a perfect case of the dichotomy 'myth-deviance'. On the one hand, Kanun protects and highly respects the persons. On the other hand, it describes precisely why, how and when a person should be killed by another. Kanun thus shows to be self-contradictory.

\subsection{The northern Albanian kinship and blood feud as a duty}

Significant literature has stopped the attention on the organization of the northern Albanian kinship (Durham 1909, Coon 1970, Resta 2002; Völl 2002, De Waal 2004, Young and Mustafa, 2008). It focused on the northern Albanian fis as the main source of authority, showing thus the impact that it has on blood feud. Gjini (maternal lineage) has no effect on blood feud, since the legitimacy is given to the fis (patrilineage). The fis is the kinship unit which has a relevant impact on blood feud (Young and Mustafa, 2008: 92). It is the nuclear family which feeds, manages the relationships and transmits blood feud generation to generation. All this process is covered by the mythical charm of the duty. The one who avenges gains the respect of its community. The Fis has its own structure and hierarchy, that intervenes in case of conflicts. The Elders occupy the top of such a hierarchy. This way of kinship organisation, where the male is at the centre and blood is avenged with blood, appears to be a community based on violence. Long ago ${ }^{1}$ blood feud has been placed within the civilities based on violence. According to this standpoint, the increases of blood feuds is due to the admiration of these

\footnotetext{
${ }^{1}$ Blood feud in Albania has been interpreted also under the light of biological, psychoanalytical and racial theories. In his book 'Criminal man' (L'uomo delinquente), Cesare Lombroso, defines Albanians as an innate criminal race. '[T]he Arab and the Albanian race are more prone to crimes of blood, less inclined instead to crimes against property.' (Lombroso, 1897: 15, my translation). Such an interpretation has been since a long time outdated. And, as experience indicates, it can easily lead to stereotypes. Still, Lombroso's standpoint is interesting regarding blood feud, as shown above.
} 
heroic actions, and the consideration of the revenge as a duty (Lombroso, 1897: 21). Other scholars also focused on the moral obligation of the phenomenon. Blood feud was for northern Albanians 'a solemn duty, recognised by both sides' and guided by precise rules (Durham 1928: 16). Nevertheless the solemn nature of this phenomenon, blood feud was one of the main reasons of male's homicides. Their lives were affected by blood feud from birth to death (Durham, 1909: 41).

Blood feud is more present in the northern Albania because of the country-isolation. The literature suggests that there is a strong association between feuding and isolation.

'Merturi-Nikaj [region] is the more closely associated with isolation and intense feuding (Coon, 1970: 35)'. Furthermore, the development of the structure of clans or tribes in Albania and Kosovo is due to the isolation from the rest of Europe. In such an inaccessible context, where the nationally enforced system of justice couldn't be present, predominated the customary laws, such as Kanun.

\subsection{Blood feud and the mistrust of people in the Albanian Justice Institutions}

The lack of an efficient law in Albania, during the years taken into analysis, and the failure of government authorities to enforce the law, pushed people to re-trust and apply Kanun. This return made possible the emerging of old social conflicts, resulting in numerous murders. Individual problems turned to be political. The individual need for protection turned to be a collective request, which found an answer in Kanun (Lemel, 1998; De Waal, 2004). The land distribution to the hereditary owners by 1992, in the aftermath of the collapse of the communist state, needed the precise rules of Kanun (De Waal 2004). Also the collapse of the government during the Civil War, in 1997, reinforced the trust in Kanun. In this light, blood feud is strongly connected with the security and the economic transition in Albania. 'In the absence of an effective state the Kanun has been used to regulate society, economic relations and property rights.' (Lawson and Saltmarshe, 2000: 138). Furthermore, the mistrust of people in the Albanian Justice Institutions (JPCA, 2010) due to its failure to function, reinforced the trust not only in Kanun but also in the role of the Council of Elders (Pleqëria) in resolving conflicts. People involved in blood feud refer to Elders instead of the Albanian authorities, as they consider them 'more experienced mediators' (Young and Mustafa, 2008: 101). 'The small-scale face-to-face nature of village life and the symbolic importance attached to the Kanun gave the pleqëria a moral force that certainly did not exist at any other level of government.' (De Waal, 2004: 26).

From this standpoint not much has changed compared to one century ago: 'The law in the Albanian mountains is administered by a council of Elders.' (Durham, 1909: 27). The mistrust of people in the Albanian Justice Institutions reveals the insufficient work done by these institutions (JPCA, 2010).

\subsection{The static and the dynamic aspects of blood feud}

Blood feud in Albania shows two different aspects: the static and the dynamic aspect. In the first case, blood feud can be considered a habitus (Völl 2002). The internalization process of the Albanian customary right has come unconsciously, as a consequence of habitus. Habitus are not the product of singular people, they have a collective nature (Bourdieu, 1977). This nature gives to blood feud a real power. From such a perspective, blood feud seems to have socially-shared-roots. The static aspect of blood feud is strongly connected with the mythology, also with the power of the patrialineage. For what concerns this aspect of the phenomenon, it can be predictable since it respects the rules of Kanun.

The other aspect of blood feud is the dynamic one. It is more complex, since it has to deal with the deviation and the changes of Kanun (Grutzpalk 2002). 'Blood feud is adapted to circumstances rather than closely aligned to the textual tradition.' (Schwandner-Sievers, 2001: 97). When blood feud shows the dynamic aspect, it is difficult to control and to predict it. Schwander-Sievens (1995: 123) quotes one of her interviewees: 'If they kill one of us we will kill 10 of them'. Such an affirmation highlights the split between Kanun and its practice. It is also stated by the Albanian studies: 'Kanun nowadays has taken some distinctions or features which were neither described nor predicted in it.' (JPCA, 2010: 75).

\section{Blood Feud in Figures}

In this chapter we are going to consider two main points. First, the impact that blood feud has on the Albanian criminality. Second, the trust of people in the Albanian Justice Institutions.

According to the Committee of Nationwide Reconciliation, during the so called 'transition years' (from 1992 to 2012, i.e. from the Communist regime's end to nowadays) about the $15 \%$ of the Albanian total homicides (10.446) is due to killings for revenge and blood feud. The Committee of Nationwide Reconciliation data are rejected by the Albanian government as too high. We consider them since other studies conducted show approximately the same results. 
Table 1. Total Intentional Homicides in Albania by motivation (1992-2012)

\begin{tabular}{lcc}
\hline Reasons of homicides & No. of death toll & Percentage \\
\hline For revenge and blood feud & 1,567 & 15.0 \\
Trivial reasons & 1,358 & 13.0 \\
Property reasons & 397 & 3.8 \\
Suicides & 864 & 8.3 \\
Accidental killings & 157 & 1.5 \\
Unregistered* & 6,103 & 58.4 \\
\hline Total & 10,446 & 100.0 \\
\hline
\end{tabular}

$\left({ }^{*}\right)$ : According to the source, the 6.103 other killings are unregistered, mainly during 1990-91-92 and 1996-97-98.

Source: Committee of Nationwide Reconciliation

Out of the 36 Albanian districts, the 7 districts shown in table 2 constitutes $65 \%$ of the total death toll in Albania. That is, a total of 6.864 homicides compared to 29 other districts, which constitute $34.3 \%$ of death toll (3.583 homicides). The sum of the first two districts, Tirana and Shkodra, is more than the total amount of the other 29 districts altogether.

Table 2. Average and Rate per year of Intentional Homicides in the Albanian districts (1992-2012)

\begin{tabular}{lcccc}
\hline $\begin{array}{l}\text { District } \\
\text { Name }\end{array}$ & $\begin{array}{l}\text { Abs. val. of Intentional } \\
\text { Homicides } \\
\text { (Total 1992-2012) }\end{array}$ & $\begin{array}{l}\text { Average per year of } \\
\text { Intentional Homicides } \\
(\text { 1992-2012) }\end{array}$ & $\begin{array}{l}\text { Average } \\
\text { Population } \\
(2001-2012)^{*}\end{array}$ & $\begin{array}{l}\text { Rate per year of } \\
\text { Intentional Homicide per } \\
\text { 100.000 inhabitants }\end{array}$ \\
\hline Tirana & 2,466 & 117.43 & 679,918 & 17.27 \\
Shkodra & 1,839 & 87.57 & 238,285 & 36.75 \\
Fieri & 627 & 29.86 & 349,852 & 8.53 \\
Vlora & 574 & 27.33 & 188,263 & 14.52 \\
Berati & 490 & 23.33 & 168,329 & 13.86 \\
Durresi & 470 & 22.38 & 254,343 & 8.80 \\
Elbasani & 397 & 18.90 & 329,149 & 5.74 \\
Other 29 & 3.583 & 170.62 & 749,362 & 22.77 \\
Districts & 10,446 & 497.43 & 2.957 .502 & 16.82 \\
\hline Total & \multicolumn{3}{c}{} \\
\hline
\end{tabular}

Source: Ibid. - (*): INSTAT

As shown by table 2, the district of Tirana has more than double the number of the population (year 2001) and three times more (year 2013) than the district of Shkodra. Nevertheless, between these two main districts there is a difference of only $6 \%$ of intentional homicides' death toll during the transition years. Instead, the district of Shkodra has approximately the same number of population as the district of Durresi, but the rate of intentional homicides is far from being equal: $17,6 \%$ compared to $4,5 \%$ (table 2). That is, the rate of Shkodra is almost four times higher than the rate of Durresi.

As shown by the above tables the crime rate is higher in the districts of Tirana and Shkodra. In 2012 the population of district of Tirana was four times that of Shkodra (it was two times in 2001). During the years of the transition it is observed that the number of intentional homicides committed in Shkodra (1.839) is about three quarters that of Tirana (2.466). This means that the incidence of intentional homicides in the district of Shkodra is much higher that of Tirana. Considering that, according to the data, during the years of transition the $15 \%$ of the intentional homicides is due to blood feud, it is likely that the incidence of the blood feud of the total intentional homicides committed in Shkodra is higher that of Tirana. As demonstrated by the studies reviewed in the preceding paragraphs, this could be considered due to the heavy roots that Kanun has in the society of northern Albania.

We consider now the data of Justice and Peace Commission of Albania (JPCA), that in 2010 made a very in depth study on blood feud in Albania. Their study focused on 'twelve districts of the country, where the phenomenon is sharper' (JPCA, 2010: 15). The numbers about the district of Shkodra shown in table 3 and in table 4 are alarming. 
Table 3. Homicides for Blood Feud occurred in Shkodra's district in 2006-2008

\begin{tabular}{cccc}
\hline Year & $\begin{array}{c}\text { Abs. val. of victims for } \\
\text { Blood Feud }\end{array}$ & $\begin{array}{c}\text { Shkodra's district } \\
\text { Population* }^{*}\end{array}$ & $\begin{array}{c}\text { Rate in \% of Homicides for Blood Feud per } \\
100.000 \text { inhabitants }\end{array}$ \\
\hline 2006 & 11 & 241,923 & 4.55 \\
2007 & 13 & 238,238 & 5.46 \\
2008 & 21 & 233,881 & 8.98 \\
\hline
\end{tabular}

Source: Justice and Peace Commission of Albania, Caritas Albania and France Caritas, (*) INSTAT

In 2006, in the district of Shkodra, there were 4 people out of 100.000 inhabitants killed for blood feud. In 2008 there were 9 people out of 100.000 inhabitants killed for blood feud.

As shown by table 4, the homicides for blood feud in the district of Shkodra constitute almost $13 \%$ of the total number of intentional homicides in year 2006, 12\% in year 2007 and almost $23 \%$ in 2008 . According to these figures, the impact that blood feud has on the entire Albanian criminality is very significant. During the years 2006-2008, the district of Shkodra constituted the $7 \%$ of the entire Albanian population. On the other hand, the district of Shkodra produced almost $13 \%$ in $2006,12 \%$ in 2007 and almost 23\% in 2007 of the entire national homicides.

Table 4. Percentage of Blood Feud homicides occurred in Shkodra's district in 2006-2008

\begin{tabular}{lccc}
\hline & 2006 & 2007 & 2008 \\
\hline Albania's population & 3.179 .573 & 3.166 .222 & 3.156 .608 \\
Abs. value of Intentional Homicides & 88 & 105 & 92 \\
\% of No. Blood feud in Shkodra's district/ No. of Intentional Homicides & 12,55 & 12,39 & 22,76 \\
\% of Shkodra's district population /Albania's population* & 7,61 & 7,52 & 7,41 \\
\hline
\end{tabular}

Source: Justice and Peace Commission of Albania, Caritas Albania and France Caritas, $\left(^{*}\right)$ INSTAT

As we discussed in the previous paragraphs, one of the main reasons of the increasing crime rate for blood feud could be the weakness of the State. The weakness of the State leads people to mistrust the Justice Institutions. For such a purpose, it would be useful to consider the trust and the mistrust in the Albanian Justice Institutions. The data regarding the trust and the mistrust are based on a questionnaire drafted and applied to 20 high schools for youths in different districts of Albania (JPCA, 2010: 15).

Table 5. The percentage of trust and mistrust in the Albanian Justice Institutions (2010)

\begin{tabular}{lcc}
\hline Age group & Trust in percentage & Mistrust in percentage \\
\hline Adults & 12 & 88 \\
Youth & 20 & 80 \\
\hline
\end{tabular}

Source: Justice and Peace Commission of Albania, Caritas Albania and France Caritas.

The general mistrust towards the Albanian Justice Institutions, and the high rate of homicides for blood feud per 100.000 people in the 2006-2008, show that blood feud is a well-rooted phenomenon that is apt to perpetuate crime.

\section{Albania's Crime versus Other Countries}

In this section we compare Albania with other countries, in order to consider the impact of blood feud on a larger scale. The analysis focuses on other 25 Europe and Central Asia countries. Through this analysis we are trying to present the situation regarding the intentional homicides in Balkan countries, and in some of the former Soviet Union countries. The analysis considers also Italy and Ireland, where blood feud still exists in some parts of these countries. Kosovo is missing in our analysis, due to the lack of a dataset. It could have been very interesting to compare Kosovo with Albania, considering the fact that blood feud is also very common there.

The lack of data for all the 26 countries that cover years 1992-2012, doesn't permit us to make a more reflective comparison. Nevertheless, the comparative analysis focuses on five available years, 2006-2010. 
As shown by table 6, after Montenegro, Albania registers the highest crime rate among Balkan countries. Albania and Montenegro have a strong ethnic Albanian component, and blood feud is present in both countries. On the other hand, Albania occupies the $14^{\text {th }}$ place among the 26 analyzed countries. Albania is almost at the center. This ranking shows that blood feud does not have a significant impact on a larger scale, since Albania occupies the $14^{\text {th }}$ place.

Table 6. Rate per year of Intentional Homicides of 26 Europe and Central Asia Countries (2006 -2010)

\begin{tabular}{|c|c|c|c|}
\hline Country Name & $\begin{array}{l}\text { Average population } \\
(2006-2010)\end{array}$ & $\begin{array}{l}\text { Average Intentional homicides per 100,000 people } \\
(2006-2010)\end{array}$ & Ranking \\
\hline Albania & $3,160,746$ & 3.12 & 14 \\
\hline Belarus & $9,537,800$ & 6.17 & 6 \\
\hline Bosnia and Herzegovina & $3,860,879$ & 1.74 & 19 \\
\hline Bulgaria & $7,620,319$ & 2.19 & 16 \\
\hline Croatia & $4,431,360$ & 1.44 & 21 \\
\hline Cyprus & $1,076,547$ & 1.31 & 23 \\
\hline Estonia & $1,341,265$ & 6.08 & 7 \\
\hline FYR of Macedonia & $2,098,392$ & 2.00 & 18 \\
\hline Georgia & $4,406,780$ & 5.97 & 8 \\
\hline Greece & $11,233,715$ & 1.23 & 24 \\
\hline Ireland & $4,395,250$ & 1.38 & 22 \\
\hline Italy & $59,765,010$ & 1.00 & 25 \\
\hline Kazakhstan & $15,776,608$ & 10.45 & 3 \\
\hline Kyrgyz Republic & $5,327,340$ & 10.59 & 2 \\
\hline Latvia & $1,341,265$ & 4.39 & 10 \\
\hline Lithuania & $3,350,818$ & 7.93 & 4 \\
\hline Moldova & $3,572,039$ & 6.75 & 5 \\
\hline Montenegro & 618,557 & 3.18 & 13 \\
\hline Romania & $21,513,312$ & 2.04 & 17 \\
\hline Russian Federation & $142,169,800$ & 12.24 & 1 \\
\hline Serbia & $7,351,122$ & 1.49 & 20 \\
\hline Slovenia & $2,026,911$ & 0.73 & 26 \\
\hline Tajkistan & $7,283,104$ & 2.52 & 15 \\
\hline Turkey & $70,372,997$ & 3.83 & 12 \\
\hline Turkmenistan & $4,919,666$ & 4.23 & 11 \\
\hline Ukraine & $46,295,860$ & 5.94 & 9 \\
\hline
\end{tabular}

Source: World Development Indicators

\section{Discussion}

A specific data set regarding blood feud in Albania is not available. The information on blood feud we consider is drawn from different sources. First, from the Annual Analyze of the Work of the Committee of Nationwide Reconciliation for the year 2012, in collaboration with the police.

The data cover 21 years, 1992-2012. As far as we know, there is not any data available that covers previous years. The information about the total Albanian population is drawn from the Albanian Statistical Institute (INSTAT) and the World Bank. Furthermore, we utilized the data drawn from a study conducted in 2010, by the Justice Peace Commission of Albania in collaboration with Caritas Albania and France Caritas.

There are three relevant perplexities concerning the utilized data. First, the data drawn from the Committee of Nationwide Reconciliation have several ambiguities regarding the figures and the definition of several topics. A very accurate revision is needed to be done. For instance, suicide is mentioned as a reason of homicides (table 1 ). But, there is not any available data that connect suicides with blood feud. Furthermore, there are 6.103 unregistered homicides out of 10.446 (table 1). This number represents more than the half of the total intentional homicides, and we have no deeper information about it. A second perplexity is the fact that the data regarding the total Albanian population, drawn from INSTAT, do not strictly correspond to the data drawn from the Worldbank dataset. The third and the last perplexity is regarding the police as a source. On the one hand, the Committee of Nationwide Reconciliation declared the collaboration with the police in order to get the data. On the other hand, the Justice Peace Commission of Albania, Caritas Albania and France Caritas declared that the police stated that it cannot deliver any information regarding blood 
feud. Nevertheless, they published some authorized police data for district of Shkodra. 'According to the latest verdict taken in 2008', the police is not authorized 'to deliver any data or information on the issue of blood feud. The reason why the General Prosecution Office has decided not to give out any information on the issue, remains unclear.' (JPCA, 2010: 42). This statement is also confirmed by other scholars, as Lawson and Saltmarshe (2000: 137): 'The major problem in assessing the extent of crime lay in the fact that the government classified crime statistics as state secrets for fear to them being used against it for political purposes.'

The lack of a national database to provide information on blood feud in Albania, does not permit an extensive sociological study about the phenomenon, despite the great attention that it has obtained from the anthropological perspective as shown in the previous paragraph.

This study revealed a significant impact of blood feud on the Albanian criminality. It also showed that blood feud is an Albanian issue, not only local. The phenomenon is sharper in the district of Shkodra due to isolation, to economic difficulties and weak presence of the state across the territory. These problems contributed to re-trust Kanun, as a need for law and order. Considering the fact that in 1997 Albania went through a Civil War, we might argue that blood feud increases in case of political instability (Lemel 1998, de Waal 2004, Lawson and Saltmarshe, 2000, Littlewood 2002).

Albania occupies the second highest crime rate among Balkan countries, excluding Kosovo. Considering the percentages of intentional homicides for blood feud during years 1992-2012, we might claim that blood feud significantly affects the life of Albanians.

The results suggest that blood feud is a phenomenon that is apt to perpetuate crime in Albania, generation after generation. Kanun and blood feud have socially-accepted roots.

Such a phenomenon needs to be studied further, especially from a sociological perspective. Accurate data sources could help to realize a deeper quantitative analysis, in order to show the severity and the consequences that brings blood feud.

\section{Conclusion}

The anthropological literature offered us a very precise description of the phenomenon. It highlighted every component of blood feud: the organization of the kinship, attitudes, values and so forth. The literature defined blood feud an old-dated phenomenon due to the isolation and other social, historical and economic reasons. Blood feud is strongly connected with the mythology. A myth is relevant for the identity of a given community. But when it becomes uncontrollable by politics, it may produce deviance. This is the case of blood feud in Albania. The weakness of the state in Albania contributed to reinforcing the trust in Kanun, as a consequence the mistrust of the National Justice Institutions.

The present study revealed that blood feud is present throughout the country, with a high significance in northern Albania, where Kanun is still practiced. The data have also revealed that the district of Shkodra has the highest crime rate among other 35 Albanian districts. This is due to blood feud.

Compared to the other countries taken into analysis, Albania occupies the second highest rate crime for years 2006-2010 among Balkan countries. Considering the percentages of intentional homicides for blood feud, we might claim that blood feud is a relevant source for the Albanian criminality. It has a great impact on the entire Albanian crime rate.

\section{References}

Bevapi K (2012) "The Albanian Custom's Right in Historical-Juridicial Aspect. A Note about Leke Dukagjini and Skanderberg's Code". European Scientific Journal 8 (7).

Justice and Peace Commission of Albania, Caritas Albania and France Caritas (2010), Blood Feud in Albania. Caritas Albania.

Coon C (1970) The Mountains of Giants. A Racial and Cultural Study of the North Albanian Mountain Ghegs. New York: Kraus Reprint Co.

De Waal C (2004) 'Post-socialist Property Rights and Wrongs in Albania: An Ethnography of Agrarian Change'. SAGE Publications 2 (1). Durham E (1909) High Albania. London: Publishers to the India Office.

Durham E (1928) Some Tribal Origins, Laws and Customs of the Balkans. London: George Allen \& Unwin.

Gjeçov Sh [1989 (1933)] Kanun of Leke Dukagjini (V.Kopsaj, Transl.). Fox (ed.).

Gould R (1999) 'Collective Violence and Group Solidarity: Evidence from a Feuding Society'. American Sociological Association 64 (3).

Grutzpalk J (2002) 'Blood Feud and Modernity: Max Weber's and Emile Durkheim's Theories.' Journal of Classical Sociology 2 (2).

Lawson C, Saltmarshe (2000) 'Security and Economics Transition: Evidence from North Albania'. Europe-Asia Studies 52 (1).

Littlewood R (2002) 'Trauma and the Kanun: Two Responses to Loss in Albania and Kosova'. International Journal of Social Psychiatry 48 (2).

Lombroso C (1897) The criminal man related to anthropology, to the law and to psychiatry (V.Kopsaj, Transl.). Torino: Fratelli Bocca 


\section{Editori.}

Resta P (edited by) (1996) The Kanun of Lek Dukagjini. The moral and legal foundations of the Albanian society (V.Kopsaj, Transl.). Nardò (LE): Besa Editrice.

Resta P (2002) Thinking of the blood. Blood feud in the Albanian culture (V.Kopsaj, Transl.). Roma: Meltemi Editore.

Rivière C (1998) Introduction to anthropology (V.Kopsaj, Transl.). Bologna: Il Mulino.

Schwandner-Sievers, S, Fischer B (2002) Albanian Identities. Myth and History. Bloomington.

Völl S (2004) 'North Albanian Customary Law Kanun as Habitus', paper presented at the EASA Conference, Department of Social and Cultural Anthropology, University of Vienna.

Völl S (2004) 'The North Albanian customary law and its oral dimension' (V.Kopsaj, Transl.). PhD Dissertation, Department of Social and Cultural Anthropology, University of Marburg, Germany.

World Health Organization (2002) World Report on Violence and Health: summary. Genova.

Young, A, Mustafa M (2008) 'Feud Narratives: Contemporary Deployments of Kanun in Shala Valley, Northern Albania'. Anthropological Notebooks 14 (2). 